\title{
Ammonoid multi-extinction crises during the Late Pliensbachian - Toarcian and carbon cycle instabilities
}

\section{J. Guex ${ }^{1}$, A. Bartolini ${ }^{2}$, J. Spangenberg ${ }^{3}$, J.-C. Vicente ${ }^{4}$, and U. Schaltegger ${ }^{5}$}

${ }^{1}$ Institute of Geology, Anthropole, University of Lausanne, Switzerland

${ }^{2}$ Museum d'Histoire Naturelle, Paris, France

${ }^{3}$ Institute of Geochemistry, Anthropole,University of Lausanne, Switzerland

${ }^{4}$ Dept. of Geology, Université Pierre et Marie Curie, Paris, France

${ }^{5}$ Earth and Environmental Sciences, University of Geneva, Rue des Maraîchers 13, 1205, Geneva, Switzerland

Received: 20 August 2012 - Accepted: 3 September 2012 - Published: 19 September 2012 Correspondence to: J. Guex (jean.guex@unil.ch) and A. Bartolini (bartolini@mnhn.fr) Published by Copernicus Publications on behalf of the European Geosciences Union.

\section{Ammonoid multi-extinction crises}

J. Guex et al.

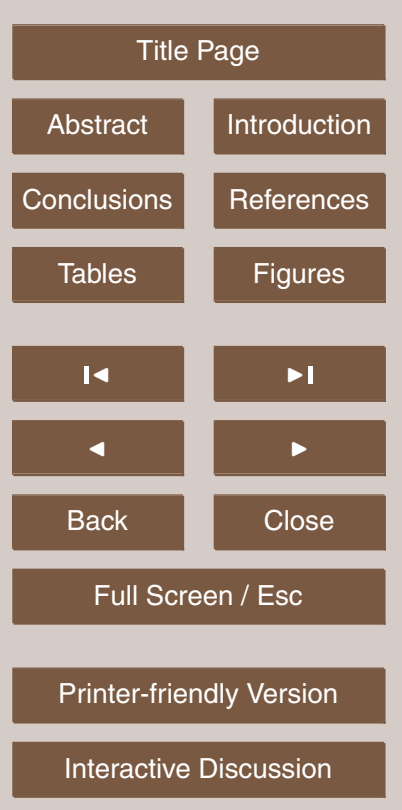

Interactive Discussion

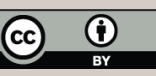




\section{Abstract}

Five crises affecting ammonite evolution occurred during the Late Pliensbachian to Late Toarcian stages (Early Jurassic). The first two (Gibbosus and end-Spinatum zones) occurred during highly cold and regressive conditions which were followed by a global anoxic event generated during a supergreenhouse warm event (Levisoni subzone) concomitant with a worldwide transgressive event. The last two (Late Variabilis and Late Insigne zones) are related to regressive events. We present new carbon isotope data from Southern Peru that demonstrate that most of the major Toarcian crises affecting ammonite evolution can be correlated with the variations affecting the $\delta^{13} \mathrm{C}$ during that unstable period. The morphogenetic reactions of the ammonites during the five different upper Liassic critical episodes are analysed, showing how this group can be used as stress indicators.

\section{Introduction}

The Toarcian Stage has been the subject of a multitude of papers, focusing mainly

on the identification and interpretation of a major anoxic event (OAE) affecting global oceans during extreme greenhouse conditions (Jenkyns, 1985, 1988; McArthur et al., 2000; Hesselbo et al., 2000; Guex et al., 2001; Morard et al., 2003; Svensen et al., 2004, 2007; van de Schootbrugge et al., 2005; Wignall et al., 2005, 2006; Cohen et al., 2007; Mattioli et al., 2008; McArthur et al., 2008; Littler et al., 2009; Suan et al., 2008, 2011; Gröcke et al., 2011; Caruther et al., 2011; Sandoval et al., 2012, etc.). A sharp negative carbon isotope excursion (CIE) associated with the OAE in both marine and continental organic matter record, as well as in carbonates, has been interpreted as evidence of an immense injection of light ${ }^{12} \mathrm{C}$ in the oceanic-atmospheric carbon reservoirs. To explain this negative $\mathrm{CIE}$, rapid release of methane from gas hydrate contained in marine continental-margin sediments, due to global warming induced by volcanic has been supposed (Hesselbo et al., 2000). Alternatively oxidation of methane

\section{Ammonoid multi-extinction crises}

J. Guex et al.

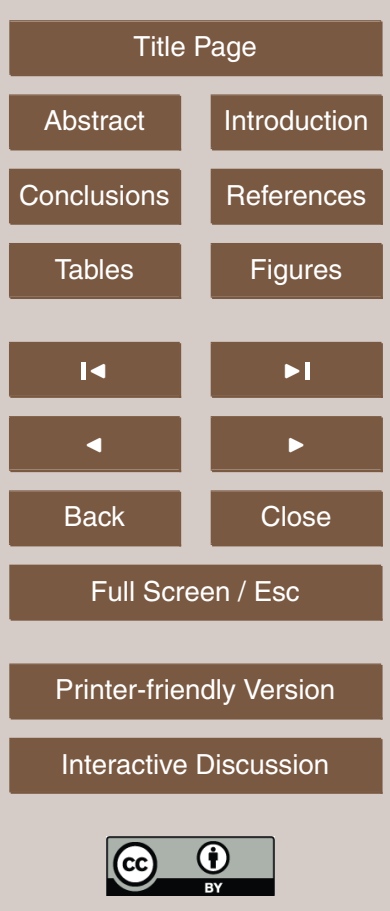


gas generated by subsurface thermal metamorphism during magmatic intrusion of the Karoo-Ferrar traps has been proposed (McElwain et al., 2005; Svensen et al., 2007).

More recently, several papers refer to a cooling phase, probably related to a brief glaciation, that preceded the OAE during the latest Pliensbachian (Guex et al., 2001;

5 Morard et al., 2003; Dera et al., 2010). The Pliensbachian-Toarcian transition is also characterized by a small negative $\mathrm{CIE}$, related to a very different environmental scenario (regression and cooling) when compared to the Early Toarcian CIE (transgression, super-greenhouse, ocean anoxia). Both the Late Pliensbachian and Early Toarcian (Semicelatum Zone) intervals are characterized by two successive extinction 10 crises, which affected several different groups of microfossils (Bartolini et al., 1992; Wignall et al., 2006; Mailliot et al., 2009; Arias, 2009; Mattioli et al., 2009) and macrofaunas (Vörös, 2002; Aberhan and Fürsich, 2000; Macchioni and Cecca, 2002; Dera et al., 2010; Garcia Joral et al., 2011). The benthic fauna was touched by the Early Toarcian OAE, while the nektonic fauna such as ammonites was affected by double ex15 tinction events, the Late Pliensbachian event being much more severe than the Early Toarcian one (Morard et al., 2003).

Essentially the entire Toarcian stage was a time interval punctuated by environmental instabilities, as highlighted by two further ammonite extinction crises at the VariabilisThouarsense and Insigne-Levesquei boundaries. However, these two crises episodes have been the subject of only a very few paleontological and geochemical studies (Guex, 1992; Sandoval et al., 2012).

In this paper (1) we present new carbon isotope data from carbonates $\left(\delta^{13} \mathrm{Ccarb}\right)$ covering part of the Toarcian, starting from the Tenuicostatum Zone up to the lower Insigne Zone constrained by precise new ammonite biochronology from southern Peru; 25 (2) we correlate this new Toarcian Pacific $\delta^{13}$ Ccarb curve with the European record (Sandoval et al., 2012) to evaluate its potential for global use; (3) we match the carbon isotope fluctuations with the ammonite taxonomic richness curve (Dera et al., 2010) recalibrated according to our new biochronological data and interpretations; (4) we evaluate whether the Middle-Late Toarcian ammonite extinction event coincides with a

\section{SED}

4, 1205-1228, 2012

\section{Ammonoid multi-extinction crises}

J. Guex et al.

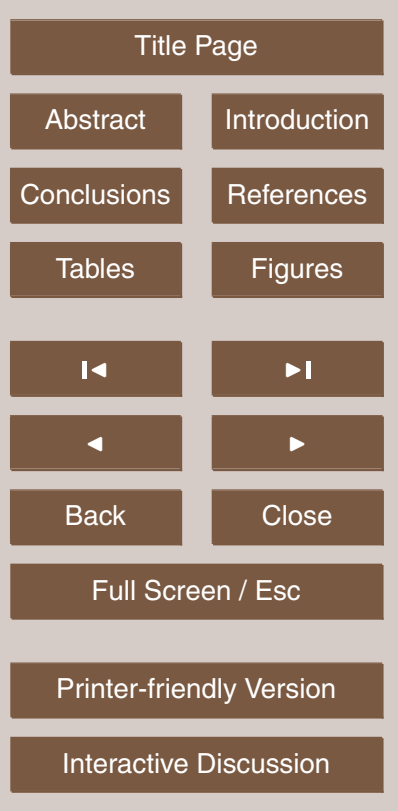


major carbon cycle perturbations such as the Late Pliensbachian and the Early Toarcian ones; (5) we discuss ammonite morphogenetic reactions during all intervals of environmental instability during the Toarcian because ammonites can, in fact, develop atavistic morphologies during episodes of environmental stress (Guex, 1992); and fi5 nally; (6) we propose a new scheme for correlating the Peruvian ammonite sequence, and the Canadian and European ammonite zonations. The latter has implications for the calibration of Late Pliensbachian to Late Toarcian events from diverse sedimentary sequences dated by fossils, previously addressed by Palfy et al. (1997); Palfy and Smith (2000); Palfy (2008); Ogg et al. (2008); Jourdan et al. (2005, 2008); and Mazzini 10 et al. (2010).

The ammonite biological crises and carbon cycle perturbations cannot be accurately correlated with the currently published geochronological ages established in the KarooFerrar province, with one exception: the age of the lower Toarcian CIE proposed by Svensen et al. (2007) and Polteau et al. (2011), $182.7 \pm 0.4 \mathrm{Ma}$.

\section{Litho and biostratigraphy of the Palquilla section (southern Peru)}

The stratigraphic section presented in this paper is located near the village of Palquilla, close to Tacna in southern Peru (GPS coordinates: $17^{\circ} 36.703^{\prime} \mathrm{S}, 70^{\circ} 00.860^{\prime}$ W; Fig. 1). It belongs to the upper levels of the Pelado Formation defined by Wilson and García (1962). Paleogeographic significance and position of the section within the Arequipa 20 Basin was discussed by Vicente $(1981,1989,2005)$ and by Vicente et al. (1982). The stratigraphy of the Cerro Taracollo area, which includes the section of Palquilla, was first studied by Salinas (1986). This study demonstrated that the local stratigraphic sequence, mainly carbonate, corresponded to a transgressive event initiated during the Sinemurian, starting with slope deposits that culminated during the Middle Toar-

\section{SED}

4, 1205-1228, 2012

\section{Ammonoid multi-extinction crises}

J. Guex et al.

\section{Title Page}

\section{Abstract}

Introduction

Conclusions

Tables

References

\section{Figures}

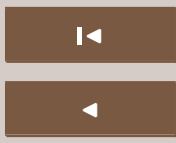

$\rightarrow 1$

Back

Close 
resediments and by tephras produced by a magmatic arc located to the SW of the studied area.

The Palquilla section, illustrated in Fig. 2, starts with a thick and massive Late Pliensbachian condensed limestone bed full of brachiopods and bivalves. This bed is over-

5 lained by white laminated shales (bed 2) yielding a thin shelled bivalve, Bositra, and a finely ribbed Dactylioceras (D. kanense) (see Jakobs, 1997, PI. 1, Figs. 19 and 20) belonging to the Tenuicostatum zone. In beds 3 and 13 we found Hildaites striatus (Guex, 1973, Pl. 3, Fig. 10), with a few intercalated Dactylioceras and Eodactylites indet., assigned to the Levisoni subzone. bed 20c provided Porpoceras (cf. vortex: see 10 Buckman, 1911, PI. 29A) and Dactylioceras with quadrangular whorl section. Higher in the section (bed 30c) we found the last local representatives of the family Dactylioceratidae (sp. indet. and Porpoceras). About $100 \mathrm{~cm}$ below bed 70 , we collected well preserved fragments of Grammoceras, Podagrosites and Hammatoceras, and bed 83 produced one specimen of Yakounia (Jakobs et al., 1994, PI. 5, Fig. 11) assigned to 15 the Thouarsense zone. Typical Pseudogrammoceras and Hammatoceras have been found about $40 \mathrm{~m}$ above Yakounia, still indicating a lower Insigne zone age, and Dumortieria of the Levesquei zone occur about $100 \mathrm{~m}$ above. In summary the Toarcian sequence at Palquilla is mostly complete, but there is a gap corresponding to the lowermost Toarcian where the Mirabile and a part of Semicelatum subzones are probably 20 very condensed if not partially missing. Note that lower Toarcian black-shales which are often associated to the CIE are not present in the section.

\section{Correlation with Canadian and Europe ammonite standard zonations}

The correlation of the Palquilla Toarcian ammonite sequence described above, the Canadian zonation of Jakobs et al. (1994) and the zonation used in Europe is given in 25 Fig. 3.

Most of the ammonite correlation is easy because Jakobs et al. (1994) collected very diagnostic taxa. In Canada, the base of the Kanense zone contains finely ribbed

SED

4, 1205-1228, 2012

\section{Ammonoid multi-extinction crises}

J. Guex et al.

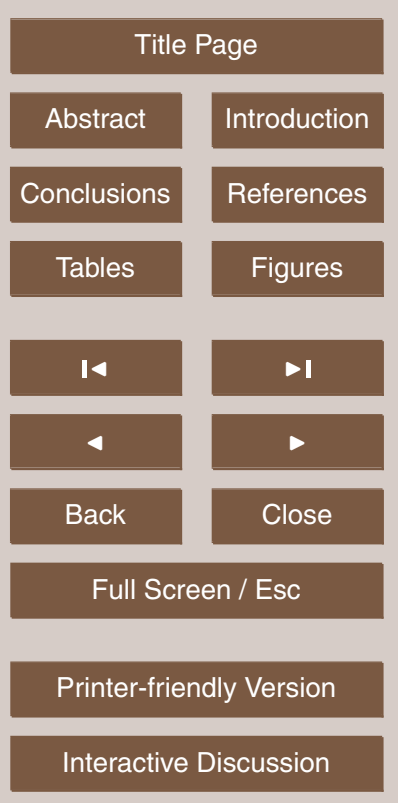

Interactive Discussion

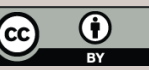


Dactylioceras (group of $D$. kanense, see above), followed by Hildaites from the Levisoni subzone. Rarenodia planulata Venturi (1975, PI. 1, Fig. 7), occurring in the Planulata zone, is a known from the top of the Falciferum zone to the base of the Bifrons zone. Denckmannia crassicosta (= Phymatoceras crassicostata Merla in Jakobs et al., 1994, 5 Pl. 3, Figs. 5 and 6) and Merlaites (Crassicostata zone) are restricted to the Variabilis zone and Podagrosites first occurs in the upper part of this zone. Grammoceras spp characterizes the Thouarsense zone. The upper Toarcian Yakounensis zone is more difficult to interprete because some ammonites assigned to Dumortieria and Pleydellia by Jakobs et al. (1994) are in fact related to Grammoceras and Pseudolilia which occur 10 in the Insigne/Dispansum subzones. In other words they are older than the Levesquei zone. In particular, the Canadian "Pleydellia" maudensis (Jakobs et al., 1994, PI. 5, Figs. 1 and 2) is a typical Pseudolillia with a clearly tabulated ventral area (Guex, 1975, PI. 8, Fig. 7). Dumortieria assigned to $D$. cf. dumortieri, cf. levesquei and insignisimilis are true Dumortieria of Levesquei age but Dumortieria? phantasma (Jakobs et al., 15 1994, PI. 5, Figs. 19 and 20) is a smooth Grammoceratid and "Pleydellia" crassiornata (Jakobs et al., 1994, PI. 5, Figs. 3 and 4) is interpreted as a strongly costate and bifurcate Grammoceratid, with a trend to develop weak umbilical nodes. Such bifurcate Grammoceratids are known in the Thouarsense zone in Europe (e.g. G. aff. comptum sensu Gabilly, 1975, PI. 18, Figs. 9 and 10).

\section{Carbon isotope record at Palquilla and global correlations}

Carbon and oxygen isotope analyses of aliquots of whole rock samples were performed using a Thermo Fisher Scientific Gas Bench II carbonate preparation device connected to a Delta Plus XL isotope ratio mass spectrometer (IRMS) at the University of Lausanne (Switzerland). The $\mathrm{CO}_{2}$ extraction was done by reaction with anhydrous phosphoric acid at $70^{\circ} \mathrm{C}$. The stable carbon and oxygen isotope ratios are reported in the delta $(\delta)$ notation as the per mil $(\% \circ)$ deviation relative to the Vienna Pee Dee belemnite standard (VPDB). The standardization of the $\delta^{13} \mathrm{C}$ and $\delta{ }^{18} \mathrm{O}$ values relative to the

\section{SED}

4, 1205-1228, 2012

\section{Ammonoid multi-extinction crises}

J. Guex et al.

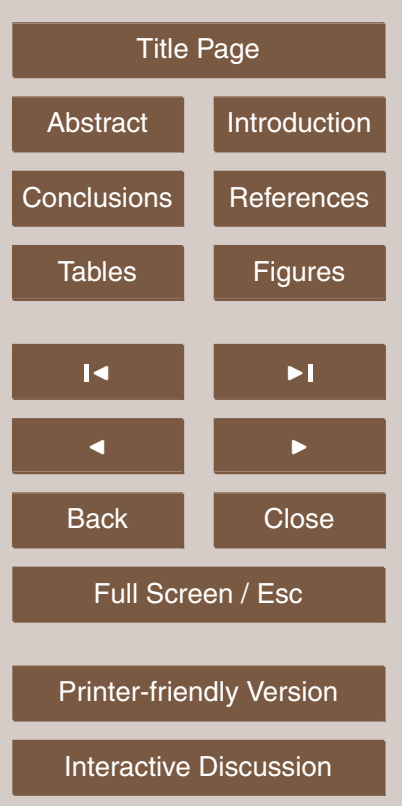


international VPDB scale was done by calibration of the reference gases and working standards with IAEA standards. Analytical uncertainty (2s), monitored by replicate analyses of the international calcite standard NBS-19 and the laboratory standards Carrara Marble is no greater than $\pm 0.05 \%$ for $\delta^{13} \mathrm{C}$ and $\pm 0.1 \%$ for $\delta^{18} \mathrm{O}$.

5 The variations of $\delta{ }^{13}$ Ccarb isotopes at Palquilla are given in Fig. 2 . The values stay low around $0 \%$ across the Pliensbachian-Toarcian boundary. Similar low values have been documented for the well expanded Peniche section in Portugal, GSSP of the Pliensbachian/Toarcian boundary (Hesselbo et al., 2007). A minor negative inflexion in coincidence with the first Hildaites striatus beds (base of Levisoni subzone) is cor10 relative with the Early Toarcian OAE negative CIE. This event corresponds at global scale with an increase in marine organic matter, well documented in several sections in Western Europe and elsewhere, and very recently also from the Southern Hemisphere Neuquén Basin in Argentina (Al-Suwaidi et al., 2010) and at high polar latitudes (Suan et al., 2011). However, at the Palquilla section, this negative CIE does not co-occur 15 with black-shales in the outcrop. The fact that in the Palquilla area conditions during the Early Toarcian were not anoxic, could explain the lesser amplitude of the negative shift (only 1\%). In NW Europe basins where high organic matter content (up to $10 \%$ in wt) and strong anoxic conditions were documented, the negative shift can attain up to $6 \%$ (Sandoval et al., 2012). In this case, early diagenetic recycling of organic matter 20 may be responsible for ${ }^{12} \mathrm{C}$ enrichment (Küspert, 1982) and consequently for the amplification of the negative CIE. The negative CIE is likely a global perturbation, but its different amplitudes probably reflect local responses due to various paleogeographic settings and hydrographic conditions. Alternatively, the fact that in Palquilla section the lower part of the negative excursion is not so pronounced, is probably due to the presence of a gap, as mentioned above.

When completely documented, the Early Toarcian CIE culminating in the Levisoni subzone is preceded by a positive excursion starting in the Early Tenuicostatum zone (Hesselbo et al., 2007). At Palquilla this positive excursion is missing. However, the major positive shift of the Falciferum subzone is well represented in that locality. We

\section{SED}

4, 1205-1228, 2012

\section{Ammonoid multi-extinction crises}

J. Guex et al.

\section{Title Page}

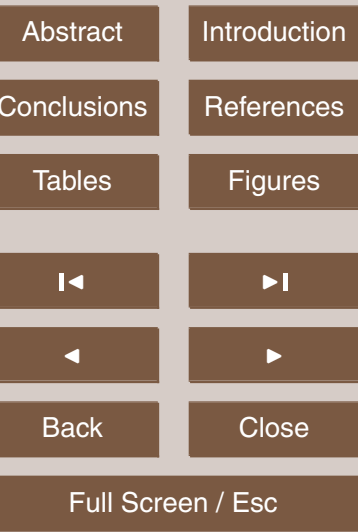

Printer-friendly Version

Interactive Discussion 
observe a trend towards negative values starting with beds containing Porpoceras (Bifrons Zone). The uppermost part of the $\delta^{13} \mathrm{C}$ curve is characterized by a steep negative shift that may have been amplified by diagenetic impact. In this part of the curve, very low $\delta^{13} \mathrm{C}$ values correspond with very low values of $\delta^{18} \mathrm{O}$. In any case

5 a negative excursion occurring in the Middle-Late Toarcian transition (Variabilis and Thouarsense zones) has also been documented in Southern France and is discussed in a general synthesis of the Toarcian $\delta^{13} \mathrm{C}$ correlations by Sandoval et al. (2012) (see Fig. 4 for comparison). In Europe this episode is related to a major regressive event, often associated with a gap. This shows that the negative excursion documented for 10 the same age interval at Palquilla is not an artefact of diagenesis and is certainly of global significance. Note that this Middle-Late Toarcian negative shift is possibly correlative with the negative excursion observed by Mazzini et al. (2010) in the Neuquen Basin (Argentina).

\section{Multi-extinctions crises during the Late Pliensbachian and Toarcian}

15 The variations in ammonite biodiversity, expressed as species richness, from the Pliensbachian-Toarcian boundary up to the lower part of the Late Toarcian (Dera et al., 2010) are calibrated to our ammonite field data and biochronological revision (Fig. 2). A first extinction event is discussed by Meister (1988, 1989; Meister and Stampfli, 2000; see also Dera et al., 2010) at the transition between the Gibbosus and Spinatum zones

20 in the Late Pliensbachian, below the stratigraphic interval studied at Palquilla. This is followed by a more marked extinction at the Pliensbachian-Toarcian boundary (C1), and is succeeded by a minor event (C2) coincident with the Early Toarcian AOE, and a major ammonite biotic crisis during the Middle-Late Toarcian transition in the upper part of the Variabilis and Thouarsense zones (C3). All ammonite biotic crises coincide with low values of $\delta^{13}$ Ccarb. In NW Europe, extinction crises C1 and C3 are clearly associated with regressive events while the crisis $\mathrm{C} 2$ is associated with transgression and anoxic conditions. In the Pacific setting of Palquilla, extinction crisis $\mathrm{C} 1$ is strongly

\section{SED}

4, 1205-1228, 2012

\section{Ammonoid multi-extinction crises}

J. Guex et al.

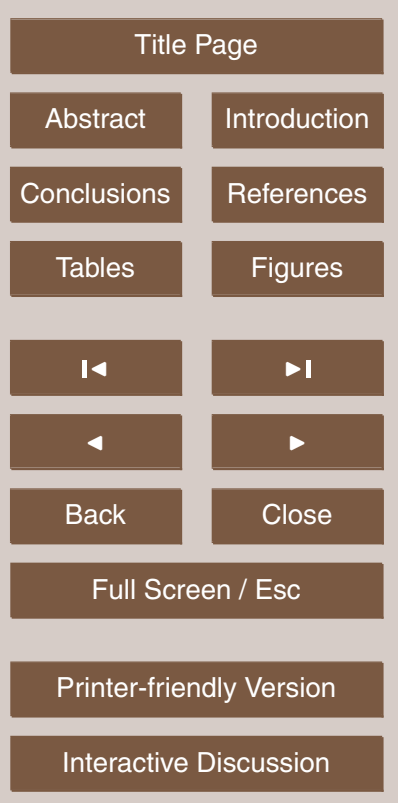

Interactive Discussion

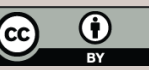


related to a low sea-level, while the local sea level variation is not clearly regressive during $\mathrm{C} 3$.

\section{Ammonites as morphological index of environmental stress}

Ammonites can be used as indicators of environmental stress thanks to their tendency 5 to develop atavistic and simple evolute morphologies during the stress episodes (Guex, 1992). Such simplified ancestral morphologies are often related to an increase in variability called covariation (Guex et al., 2003).

First observed by Buckman (1887) in Sonninia and Amaltheus and rediscussed later by Westermann (1966), covariation was originally described as follows: "Roughly 10 speaking, inclusion and compression of the whorls correlate with the amount of ornament - the most ornate species being the more evolute (i.e. loosely coiled) and having almost circular whorls..." One interesting characteristic of this phenomenon is that it usually generates extreme morphotypes of atavistic habitus. For example the evolute spinose Amaltheids generated by the "smooth" involute $A$. margaritatus strongly 15 recall the ancestral morphology of the Sinemurian Eoderoceras (Guex et al., 2003, Fig. 2). Similarly, the Middle-Late Toarcian evolute Podagrosites generated by the relatively involute Pseudogrammoceras are similar to the ancestral lower Pliensbachian Fuciniceras (Guex, 2006, Fig. 6). Other examples of atavisms occurring during high environmental stress are discussed and illustrated in Guex (2006, Figs. 4-7).

20

In the case of the Toarcian multi-crises, there is a clear negative relationship between the loss of taxonomic richness and a drastic increase of intraspecific variability, through the covariation phenomenon. Because a crisis of extinction is a clear symptom of paleoenvironmental stress, the covariation also can be linked to paleoenvironmental stress.

25 Note that the relationships between high environmental stress and increased intraspecific variability is well established since the pioneer work of Parsons (1987) and Hoffman and Parsons (1991) but clear relationships between the special case of
SED

4, 1205-1228, 2012

\section{Ammonoid multi-extinction crises}

J. Guex et al.

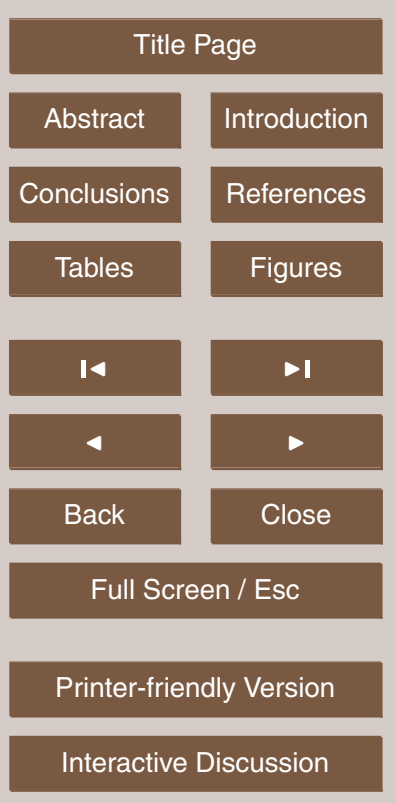

1213 
covariation and external stress has been the topic of very few papers (see e.g. Guex, 1992).

The Late Pliensbachian minor extinction event is characterized by an increase in polymorphism within the genus Amaltheus (covariation within the margaritatus- > gib-

5 bosus plexus; see Guex et al., 2003, Fig. 2) and by the appearance of the evolute Pleuroceras, derived from typical involute Amaltheids.

During the Pliensbachian-Toarcian boundary major regressive event the Dactylioceratidae reacted similar to other groups by a marked increase in variability with extreme forms leading from the depressed and strongly spinose Dactylioceras crosbeyi group 10 to serpenticone forms with simple ornamentation of the Eodactylites morphogroup, another case of typical covariation.

The Early Toarcian OAE major extinction event is characterized by the same kind of variability increase within the Dactylioceras semicelatum group which develops spinose forms with cadicone internal whorls, well described by Howarth (1973, PI. 8, Figs. 1-3). 15 This episode is also characterized by the appearance of evolute Hildoceratids known as Hildaites, derived from the relatively involute Protogrammoceratids. However the complete transition between the two groups is not well recorded.

During the Middle-Late Toarcian transition, an exceendingly important faunal turnover is observed with the disappearance of the Hildoceratids, Dactylioceratids and 20 Phymatoceratids which are replaced by the Hammatoceratids and Grammoceratids in the ammonite populations.

This crisis, like the others, is marked by a strong increase in polymorphism of the ammonites (e.g. covariation of the Haugia-Denckmannia and the PseudogrammocerasPodagrosites plexus illustrated in Guex, 2001, Fig. 5 and Guex, 2006, Fig. 6): as noted above, such variability increases are particularly important during major environmental stress episodes (see Guex, 1992, 2001 and 2006 for details).

The same kind of biotic situation occurs once more during the Late Insigne-Early Levesquei crises (Guex, 1975; Dera et al., 2010) where we observe the disappearance of abundant Osperleioceras, most typical Hammatoceratids, Alocolytoceras,

\section{SED}

$4,1205-1228,2012$

\section{Ammonoid multi-extinction crises}

J. Guex et al.

\section{Title Page}

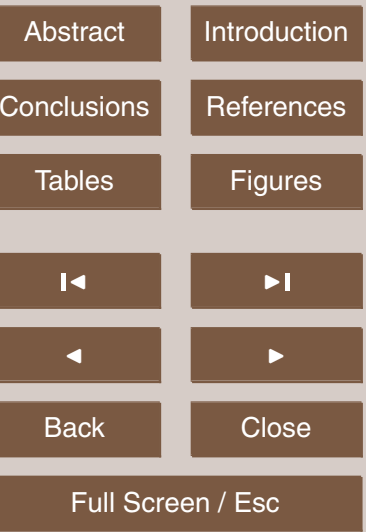

Printer-friendly Version

Interactive Discussion 
Buckmanites and Oxyparoniceras. In the topmost abundantly fossiliferous beds of the Late Insigne Zone (Dispansum subzone) we observe again a huge polymorphism in the Osperleioceras reynesi group with typical Osperleioceras like O. alterans-wunstorfi (Guex, 1975, PI. 8, Fig. 3) giving rise to simplified O. reynesi (Guex, 1975, PI. 8, Fig. 2), 5 a form characterized by an evolute coiling and simple, strong and almost straight lateral ribs (Guex, 1992, Fig. 4; Morard and Guex, 2003, Fig. 1). The same is observed in Hammatoceras of the bonarellii group (Guex, 1975, PI. 9, Fig. 12) which gives rise to serpenticone Catulloceras (Guex, 1975, PI. 2, Fig. 4), the direct ancestor of the Dumortieria and Pleydellia leading to all the Haplocerataceae of the Middle and Upper 10 Jurassic (Guex, 1992, Fig. 5).

\section{Possible relationships between the Toarcian crises and the Karoo Ferrar CFB}

In the late 80s, general opinion held that major regressive events were responsible for the major biotic changes in the marine environments (see Sandoval et al., 2001 for discussion). More recently, many major extinctions events have been correlated 5 with significant volcanic activities (Courtillot, 1995; Courtillot and Renne, 2003). In the case of the Pliensbachian - Toarcian, a correlation between the biotic events and the onset of the Karoo Ferrar LIP has been invoked by Palfy and Smith (2000); Wignall (2001) and several others. Most geochronological data concerning the Karoo and Lesotho province are due to Jourdan and colleagues and are summarized in Jourdan be strictly compared with the approximate $\mathrm{U}-\mathrm{Pb}$ ages established by Palfy and Smith (2000). Taking the ca. $0.8 \%$ systematic age bias between Ar-Ar and U-Pb dates into account (Min et al., 2000; Renne et al., 2010), the Karoo expected U-Pb age may be situated in between 178.5 and $184.5 \mathrm{Ma}$. Palfy et al. $(1997,2000)$ estimated the age of the Pliensbachian-Toarcian boundary at about $183.6+1.7 /-1.1 \mathrm{Ma}$ and the age of the Canadian Crassicostata zone (approximately equivalent to the Variabilis zone) at 181.4 Ma ( $\pm 1.2 \mathrm{Ma})$.

\section{SED}

4, 1205-1228, 2012

\section{Ammonoid multi-extinction crises}

J. Guex et al.

\section{Title Page}

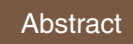

Introduction

Conclusions

References

Tables

Figures

14

DI

4

Back

Close 


\section{Conclusions}

In summary, there is a general agreement that the activity of the Karoo Ferrar LIP is likely related to the crises that affected the marine faunas during the Late Pliensbachian to Late Toarcian interval. As noted by Jourdan et al. (2008); Moulin et al. (2010) and 5 Moulin (2011) the volcanic pulses were discretely distributed through time with each being of very short duration. This fits well with the idea of a volcanogenic origin for the biotic catastrophs that characterized the ammonites during this period discussed above. Interestingly, Polteau et al. (2011) and Aarnes et al. (2011) proposed that contact metamorphism generated by the large scale intrusions of sills within the organic Ecca Group in the Karoo basin (South Africa) could lead to a huge degassing of methane, potentially inducing a supergreenhouse effect, responsible for the Early Toacian $\mathrm{OAE}$ and the negative $\mathrm{CIE}$. Thanks to a high resolution $\mathrm{U}-\mathrm{Pb}$ geochronology study of zircons from dolerites in this basin, they obtained a mean age of $182.7 \pm 0.4 \mathrm{Ma}$ for the sills. The finding of this negative shift also in the Pacific area beyond the Europe, confirms its global significance (Caruthers et al., 2011; Gröcke et al., 2011). Moreover the Palquilla data show that the Levisoni negative CIE is not exclusively associated with black-shales because in this case, the amplitude is much less pronounced.

The end-Pliensbachian extinction (crisis C1 in Fig. 2) is marked by an important diversity drop associated with a generalized sedimentary gap linked to a marked regression event in NW-Europe and the Pacific area (Marjanac and Steel, 1997). This huge regression was interpreted as due to a major short lived glaciation (Guex et al., 2001; Suan et al., 2011; see also Dera et al., 2010), probably generated by a cooling resulting from an enormous $\mathrm{SO}_{2}$ release generated in the Karoo-Ferrar area during the Late Pliensbachian, several hundred ky before the emplacement of the Karoo sills. Besides the marine regression and the lethal effect of $\mathrm{SO}_{2}$ pollution, we expect also large amounts of heavy metals and $\mathrm{Cl}$ and $\mathrm{F}$ pollution to have drastically increased the extinction rates of marine organisms. This major regression is also marked by important emersion topographies illustrated by the deposition of enormously thick conglomerates
SED

4, 1205-1228, 2012

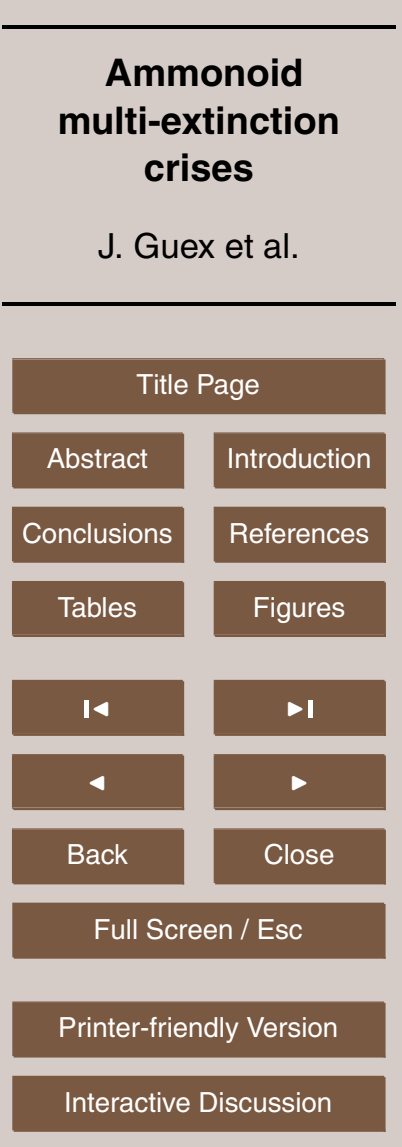

Discussion 
in the Dunlap Formation in Nevada (USA) and in the top Pliensbachian of the UruroaKawhia area, New Zealand, just below marine beds with ammonites that we identified as Dactylioceras aff. semicelatum. The cooling model is confirmed by several recent $\delta^{18} \mathrm{O}$ data (Gomez et al., 2008) and by the discovery of glendonites across the entire 5 Pliensbachian (Price, 1999).

The regression phase is followed by a worldwide transgression during the Early Toarcian, with the deposition of black shales (Toarcian OAE of Jenkyns, 1988; crisis C2 in Fig. 2) and very warm climate possibly related to the major intrusion of the Karoo sills, as mentioned above (Polteau et al., 2011). This widespread anoxic event is responsi10 ble for major extinctions in the benthic foraminifera (Bartolini 1992) and brachiopods (Garcia Joral et al., 2011) but the ammonites were only slightly affected, mostly by a moderate drop in diversity (Fig. 2).

If we except the C2 crisis of the Toarcian OAE at 182.7 Ma (see Polteau et al., 2011), the other datings are not precise enough to prove a one to one correlation between the multiple Pliensbachian to Toarcian crises and the different pulses of the Karoo Ferrar volcanism. However it is highly probable that the major regressive events observed during the crises $\mathrm{C} 1$ and $\mathrm{C} 3$ are indeed related to that volcanism, generated by cooling induced by major $\mathrm{SO}_{2}$ injections occurring prior or during these extrusive episodes, while the Levisoni crisis $\mathrm{C} 2$ and the OAE are related to the large- scale intrusion of

Acknowledgements. J. G. and A. B. thank the Swiss NSF (project 124375) and the Fondation vaudoise pour la Géologie for the support of their fieldwork in southern Peru and E. S. Carter for her editorial corrections.

\section{SED}

4, 1205-1228, 2012

\section{Ammonoid multi-extinction crises}

J. Guex et al.

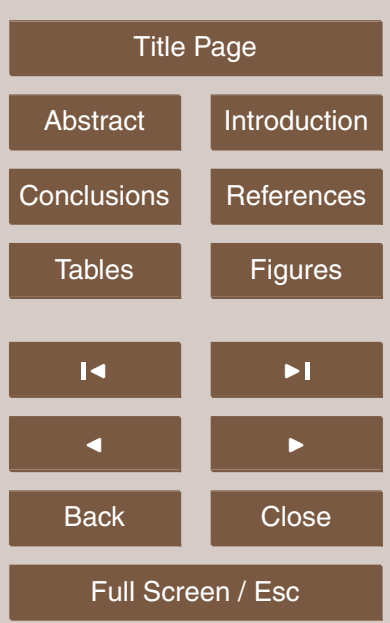

Printer-friendly Version

Interactive Discussion 


\section{References}

Aarnes, I., Svensen, H., Polteau, S., and Planke, S.: Contact metamorphic devolatilization of shales in the Karoo Basin, South Africa, and the effects of multiple sill intrusions, Chem. Geol., 281, 181-194, 2011.

5 Aberhan, M. and Fürsich, F. T.: Mass origination versus mass extinction: the biological contribution to the Pliensbachian-Toarcian extinction event, J. Geol. Soc. London, 157, 55-60, 2000.

Al-Suwaidi, A. H., Angelozzi, G. N., Baudin, F., Damborenea, S. E., Hesselbo, S. P., Jenkyns, H. C., Mancenido, M. O., and Riccardi, A. C.: First record of the Early Toarcian Oceanic Anoxic Event from the Southern Hemisphere, Neuquen Basin, Argentina, J. Geol. Soc. London, 167, 633-636, 2010.

Arias, C.: Extinction pattern of marine Ostracoda across the Pliensbachian-Toarcian boundary in the Cordillera Ibérica, NE Spain: Causes and consequences, Geobios, 42, 1-15, 2009.

Bartolini, A., Nocchi, M., Baldanza, A., and Parisi, G.: Benthic life during the Early Toarcian Anoxic Event in the Southwestern Tethyan Umbria-Marche basin, Central Italy, in: Studies in Benthic Foraminifers Benthos '90, Sendai, Tokai University Press, 323-338, 1992.

Buckman, S.: Monograph of the ammonites of the Inferior Oolite Series, Paleontogr. Soc. London, 262, 1-456, 1887.

Buckman, S.: Yorkshire Type Ammonites, I, PI. 29A, 1911.

20 Caruthers, A. H., Gröcke, D. R., and Smith, P. L.: The significance of an Early Jurassic (Toarcian) carbon-isotope excursion in Haida Gwaii (Queen Charlotte Islands), British Columbia, Canada, Earth Planet. Sc. Lett., 307, 19-26, 2011.

Cohen, A. S., Coe, A. L., and Kemp, D. B.: The Late Palaeocene-Early Eocene and Toarcian (Early Jurassic) carbon isotope excursions: a comparison of their time scales, associated environmental changes, causes and consequences, J. Geol. Soc., 164, 1093-1108, 2007.

Courtillot, V. E.: La vie en catastrophes, Dunod, 1-250, 1995.

Courtillot, V. E. and Renne, P. R.: On the ages of flood basalt events, CR. Géosci., 335, 113140, 2003.

Dera, G., Neige, P., Dommergues, J.-L., Fara, E., Laffont, R., and Pellenard, P.: High-resolution dynamics of Early Jurassic marine extinctions: the case of Pliensbachian-Toarcian ammonites (Cephalopoda), J. Geol. Soc., 167, 21-33, 2010.

\section{SED}

4, 1205-1228, 2012

\section{Ammonoid multi-extinction crises}

J. Guex et al.

\section{Title Page}

\section{Abstract}

Introduction

Conclusions

References

Tables

Figures

14

DI

4

Back

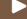

Close

\section{Full Screen / Esc}

Printer-friendly Version

Interactive Discussion 
Gabilly, J.: Evolution et systématique des Phymatoceratinae et des Grammoceratinae (Hildocerataceae, Ammonitina) de la région de Thouars, stratotype du Toarcien, Mém. S. Géo. F., 124, 1-196, 1975.

García Joral, F., Gómez, J. J., and Goy, A.: Mass extinction and recovery of the Early Toar5 cian (Early Jurassic) brachiopods linked to climate change in Northern and Central Spain, Palaeogeogr. Palaeocl., 302, 367-380, 2011.

Gómez, J. J., Goy, A., and Canales, M. L.: Seawater temperature and carbon isotope variations in belemnites linked to mass extinction during the Toarcian (Early Jurassic) in Central and Northern Spain, Comparison with other European sections, Palaeogeogr. Palaeocl., 258, 28-58, 2008.

Gröcke, D. R., Hori, R. S., Trabucho-Alexandre, J., Kemp, D. B., and Schwark, L.: An open ocean record of the Toarcian oceanic anoxic event, Solid Earth, 2, 245-257, doi:10.5194/se2-245-2011, 2011.

Guex, J.: Aperçu biostratigraphique sur le Toarcien inférieur du Moyen-Atlas marocain et dis15 cussion sur la zonation de ce sous-étage dans les series méditerrainéennes, Eclogae Geol. Helv., 66, 493-523, 1973.

Guex, J.: Description biostratigraphique du Toarcien supérieur de la bordure sud des Causses (France), Eclogae Geol. Helv., 68, 97-129, 1975.

Guex, J.: Origine des sauts évolutifs chez les ammonites, Bull. Soc. Vaud. Sc. Nat., 82, 117144, and Bull. Géol. Lausanne, 316, 117-144, 1992.

Guex, J.: Environmental stress and atavism in ammonoid evolution, Eclogae Geol. Helv., 94, 321-328, 2001.

Guex, J.: Reinitialization of evolutionary clocks during sublethal environmental stress in some invertebrates, Earth Planet. Sci. Let., 424, 240-253, 2006.

Guex, J., Morard, A., Bartolini, A., and Morettini, E.: Découverte d'une importante lacune stratigraphique à la limite Domérien-Toarcien: implications paléo-océanographiques, Bull. Soc. Vaud. Sc. Nat., 87, 277-284, and Bull. Géol. Lausanne, 345, 277-284, 2001.

Guex J., Koch, A., O'Dogherty, L., and Bucher, H.: A morphogenetic explanation of Buckman's Law of covariation, B. Soc. Géol. Fr., 174, 603-606, 2003.

so Hesselbo, S. P., Gröcke, D. R., Jenkyns, H. C., Bjerrum, C. J., Farrimond, P., Morgans Bell, H. S., and Green, O. R.: Massive dissociation of gas hydrate during a Jurassic Oceanic Anoxic Event, Nature, 406, 392-395, 2000.

\section{SED}

4, 1205-1228, 2012

\section{Ammonoid multi-extinction crises}

J. Guex et al.

\section{Title Page}

\section{Full Screen / Esc}

Printer-friendly Version

Interactive Discussion 
Hesselbo, S. P., Jenkyns, H. C., Duarte, L. V., and Oliveira, L. C. V.: Carbon-isotope record of the Early Jurassic (Toarcian) Oceanic Anoxic Event from fossil wood and marine carbonate (Lusitanian Basin, Portugal), Earth Planet. Sc. Lett., 253, 455-470, 2007.

Hoffman, A. A. and Parsons, P. A.: Evolutionary Genetics and Environmental Stress, Oxford University Press, 1-284, 1991.

Howarth, M. K.: The stratigraphy and ammonite fauna of the upper Liassic grey shales of the Yorkshire coast, Bull. Brit. Mus. Geol., 24, 237-277, 1973.

Jakobs, G. K.: Toarcian (Early Jurassic) ammonoids from Western North America, Geol. Surv. Canada, 428, 1-137, 1997,

10 Jakobs, G. K., Smith, P. L., and Tipper, H.: An ammonite zonation for the Toarcian (Lower Jurassic) of the North American Cordillera, Can. J. Earth Sci., 31, 919-942, 1994.

Jenkyns, H. C.: The Early Toarcian and Cenomanian-Turonian anoxic events in Europe: comparisons and contrasts, Geol. Rundsch., 74, 505-518, 1985.

Jenkyns, H. C.: The Early Toarcian (Jurassic) Anoxic Event: stratigraphic, sedimentary and geochemical evidence, Am. J. Sci., 288, 101-151, 1988.

Jourdan, F., Féraud, G., Bertrand, H., Kampunzu, A. B., Tshoso, G., Watkeys, M. K., and Le Gall, B.: The Karoo large igneous province: Brevity, origin, and relation with mass extinction questioned by new 40Ar/39Ar age data, Geology, 33, 745-748, 2005.

Jourdan, F., Féraud, G., Bertrand, H., Watkeys, M. K., and Renne, P. R.: The ${ }^{40} \mathrm{Ar} /{ }^{39} \mathrm{Ar}$ 20 ages of the sill complex of the Karoo large igneous province: Implications for the Pliensbachian-Toarcian climate change, Geochem. Geophy. Geosy., 9, Q06009, doi:10.1029/2008GC001994, 2008.

Kuespert, W.: Environmental changes during oil shale deposition as deduced from stable isotope ratios, in: Cyclic and Event Stratification, edited by: Einsele, G. and Seilacher, A., 25 Springer, 482-501, 1982.

Littler, K., Hesselbo, S. P., and Jenkyns, H. C.: A carbon-isotope perturbation at the Pliensbachian-Toarcian boundary: evidence from the Lias Group, NE England, Geol. Mag., 147, 181-192, 2010.

Macchioni, F. and Cecca, F.: Biodiversity and biogeography of middle-late liassic ammonoids: implications for the Early Toarcian mass extinction, Geobios, 35, 165-175. 2002.

Mailliot, S., Mattioli, E., Bartolini, A., Baudin, F., Pittet, B., and Guex, J.: Late PliensbachianEarly Toarcian (Early Jurassic) environmental changes in an epicontinental basin of NW

\section{SED}

4, 1205-1228, 2012

\section{Ammonoid multi-extinction crises}

J. Guex et al.

\section{Title Page}

\section{Abstract}

Introduction

Conclusions

References

Tables

Figures

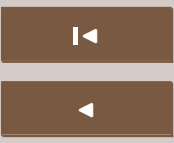

Back

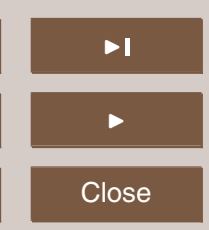

Full Screen / Esc

Printer-friendly Version

Interactive Discussion 
Europe (Causses area, central France): A micropaleontological and geochemical approach, Palaeogeogr. Palaeocl., 273, 346-364, 2009.

Marjanac, T. and Steel, R. J.: Dunlin Group sequence stratigraphy in the northern North Sea: A model for Cook sandstone deposition, A.A.P.G. Bull., 81, 276-292, 1997.

5 Mattioli, E., Pittet, B., Suan, G., and Mailliot, S.: Calcareous nannoplankton across the Early Toarcian Anoxic Event: implications for paleoceanography within the western Tethys, Paleoceanography, 23, PA3208, doi:10.1029/2007PA001435, 2008.

Mattioli, E., Pittet, B., Petitpierre, L., and Mailliot, S.: Dramatic decrease of the pelagic carbonate production by nannoplankton across the Early Toarcian Anoxic Event (T-OAE), Global Planet.

10 Change, 65, 134-145, 2009.

Mazzini, A., Svensen, H., Leanza, H. A., Corfu, F., and Planke, S.: Early Jurassic shale chemostratigraphy and $\mathrm{U}-\mathrm{Pb}$ ages from the Neuquén Basin (Argentina): Implications for the Toarcian Oceanic Anoxic Event, Earth Planet. Sc. Lett., 297, 633-645, 2010.

McElwain, J. C., Wade-Murphy, J., and Hesselbo, S. P.: Changes in carbon dioxide during an 15 anoxic event linked to intrusion of Gondwana coals, Nature, 435, 479-482, 2005.

McArthur, J. M., Donovan, D. T., Thirlwall, M. F., Fouke, B. W., and Mattey, D.: Strontium isotope profile of the Early Toarcian (Jurassic) oceanic anoxic event, the duration of ammonite biozones, and belemnite palaeotemperatures, Earth Planet. Sc. Lett., 179, 269-285, 2000.

McArthur, J. M., Algeo, T., van de Schootbrugge, B., Li, Q., and Howarth, R. J.: Basinal restric20 tion, black shales, Re-Os dating, and the Early Toarcian (Jurassic) oceanic anoxic event, Paleoceanography, 23, 1-22, doi:10.1029/2008PA001607, 2008.

Meister, C.: Ontogenèse et évolution des Amaltheidae (Ammonoidea), Eclogae Geol. Helv., 81, 763-841, 1988.

Meister, C.: Les ammonites du Domérien des Causses (France): analyses paléontologiques et stratigraphiques, Cahiers de Paléontologie du CNRS, 1-80, 1989.

Meister, C. and Stampfli, G.: Les ammonites du Lias moyen (Pliensbachien) de la Néotéthys et de ses confins; compositions fauniques, affinités paléogéographiques et biodiversité, Rev. Paléobiol., 19, 227-292, 2000.

Min, K., Mundil, R., Renne, P. R., and Ludwig, K. R.: A test for systematic errors in ${ }^{40} \mathrm{Ar} /{ }^{39} \mathrm{Ar}$ geochronology through comparison with $\mathrm{U} / \mathrm{Pb}$ analysis of a 1.1-Ga rhyolite, Geochim. Cosmochim. Ac., 64, 73-98, 2000.

Morard, A. and Guex, J.: Ontogeny and covariation in the Toarcian genus Osperleioceras (Ammonoidea), B. Soc. Géol. Fr., 174, 607-615, 2003.

\section{SED}

4, 1205-1228, 2012

\section{Ammonoid multi-extinction crises}

J. Guex et al.

\section{Title Page}

\section{Abstract}

Introduction

Conclusions

References

Tables

Figures

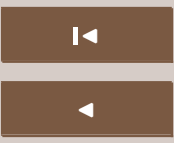

Back

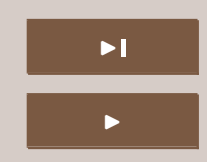

Close

Full Screen / Esc

Printer-friendly Version

Interactive Discussion 
Morard, A., Guex, J., Bartolini, A., Morettini, A., and DeWever, P.: A new scenario for the Domerian - Toarcian transition, B. Soc. Géol. Fr., 174, 351-356, 2003.

Moulin, M.: Les traps du Karoo et les extinctions du Jurassique inférieur: Dynamique éruptive et perturbations de l'environnement, Institut de Physique du Globe, Paris, unpublished thesis, 1-304, 2011.

Moulin, M., Fluteau, F., Courtillot, V., Marsh, J. S., Delpech, G., Quidelleur, X., and Gerard, M.: Magnetostratigraphy and dating of the Lesotho lava pile (Karoo traps): an attempt to constrain the timing of the eruptive sequence in relation with the end-Pliensbachian extinction event, Geophys. Res. Abst., 12, EGU2010-6557, 2010.

10 Ogg, J. G., Ogg, G., and Gradstein, F. M.: The Concise Geologic Time Scale, Cambridge University Press, 2008.

Pálfy, J.: The quest for refined calibration of the Jurassic time-scale, P. Geologist. Assoc., 119, 85-95, 2008.

Pálfy, J. and Smith, P. L.: Synchrony between Early Jurassic extinction, oceanic anoxic event, and the Karoo-Ferrar flood basalt volcanism, Geology, 28, 747-750, 2000.

Pálfy, J., Parrish, R. R., and Smith, P. L.: A U-Pb age from the Toarcian (Lower Jurassic) and its use for time scale calibration through error analysis of biochronologic dating, Earth Planet. Sc. Lett., 146, 659-675, 1997.

Parsons, P. A.: Evolutionary rates under environmental stress, Evol. Biol., 21, 311-340, 1987.

Polteau, S., Corfu, F., Svensen, H., and Planke, S.: Rapid emplacement of the Karoo Basin sill complex during the Toarcian revealed by U-Pb dating of zircons, in: EGU General Assembly 2010, Geophys. Res. Abst., 12, 2011.

Price, G. D.: The evidence and implications of polar ice during the Mesozoic, Earth-Sci. Rev., 48, 183-210, 1999.

Renne, P. R., Mundil, R., Balco, G., Min, K., and Ludwig, K. R.: Joint determination of 40K decay constants and $40 \mathrm{Ar}^{\star} / 40 \mathrm{~K}$ for the Fish Canyon sanidine standard, and improved accuracy for 40Ar/39Ar geochronology, Geochim. Cosmochim. Ac., 74, 5349-5367, 2010.

Salinas, E.: Evolución paleogeográfica del Sur del Perú a la luz de los métodos de análisis sedimentológicos de las series del Departamento de Tacna, unpublished thesis, Universidad Nacional San Agustin, Arequipa, 1-200, 1986.

Sandoval, J., O'Dogherty, L., and Guex, J.: Evolutionary rates of Jurassic Ammonites in relation to sea level fluctuation, Palaios, 16, 330-363, 2001.

\section{Ammonoid multi-extinction crises}

J. Guex et al.

\section{Title Page}

\section{Full Screen / Esc}

Printer-friendly Version

Interactive Discussion 
Sandoval, J., Bill, M., Aguado, A., O'Dogherty, L., Rivas, P., Morard, A., and Guex, J.: The Toarcian in the Subbetic basin (southern Spain): Bio-events (ammonite and calcareous nannofossils) and carbon-isotope stratigraphy, Palaeogeogr. Palaeocl., 342, 40-63, 2012.

Suan, G., Pittet, B., Bour, I., Mattioli, E., Duarte, L. V., and Mailliot, S.: Duration of the Early Toar5 cian carbon isotope excursion deduced from spectral analysis: Consequence for its possible causes, Earth Planet. Sc. Lett., 267, 666-679, 2008.

Suan, G., Mattioli, E., Pittet, B., Lécuyer, C., Suchéras-Marx, B., Duarte, L. V., Philippe, M., Reggiani, L., and Martineau, F.: Secular environmental precursors to Early Toarcian (Jurassic) extreme climate changes, Earth Planet. Sc. Lett., 290, 448-458, 2010.

10 Suan, G., Nikitenko, B. L., Rogov, M. A., Baudin, F., Spangenberg, J. E., Knyazev, V. G., Glinskikh, L. A., Goryacheva, A. A., Adatte, T., Riding, B. J., Föllmi, K. B., Pittet, B., Mattioli, E., and Lécuyer, C.: Polar record of Early Jurassic massive carbon injection, Earth Planet. Sc. Lett., 312, 102-113, 2011.

Svensen, H., Planke, S., Malthe-Sørenssen, A., Jamtveit, B., Myklebust, R., Eidem, T. R., and

15 Rey, S. S.: Release of methane from a volcanic basin as a mechanism for initial Eocene global warming, Nature, 429, 542-545, 2004.

Svensen, H., Planke, S., Chevalier, L., Malthe-Sørenssen, A., Corfu, F., and Jamtveit, B.: Hydrothermal venting of greenhouse gases triggering Early Jurassic global warming, Earth Planet. Sc. Lett., 256, 554-566, 2007.

van de Schootbrugge, B., McArthur, J. M., Bailey, T. R., Rosenthal, Y., Wright, J. D., and Miller, K. G.: Toarcian Oceanic Anoxic Event: an assessment of global causes using belemnite carbon isotope records, Paleoceanography, 20, PA3008, doi:10.1029/2004PA001102, 2005.

Venturi, F.: Rarenodia, nuovo genere di ammoniti (sottofam. Hammatoceratinae Buckman, 1887) del Toarciano inferiore "Rosso Ammonitico" umbro-marchigiano, Boll. Soc. Paleontol. I., 14, 11-19, 1975.

Vicente, J.-C.: Elementos de la estratigrafía sur-peruana, in: Cuencas sedimentarias del Jurásico y Cretácico de América del Sur, edited by: Volkheimer, W. and Musacchio, E. A., Comité Sudamericano del Jurásico y Cretácico, I, Buenos Aires, 319-351, 1981.

Vicente, J.-C.: Early Late Cretaceous overthrusting in the Western Cordillera of southern Peru, 30 in: Geology of the Andes and its relation to hydrocarbon and mineral resources, edited by: Ericksen, G. E., Cañas, M. T., and Reinemund, J. A., Houston, 11, 91-117, 1989.

\section{SED}

4, 1205-1228, 2012

\section{Ammonoid multi-extinction crises}

J. Guex et al.

\section{Title Page}

\section{Full Screen / Esc}

Printer-friendly Version

Interactive Discussion 
Vicente, J.-C.: Dynamic paleogeography of the Jurassic Andean Basin: pattern of transgression and localisation of main straits through the magmatic arc, Rev. Asoc. Geol. Argent., 60, 221250, 2005.

Vicente, J.-C., Beaudoin, B., Chavez, A., and León, I.: La Cuenca de Arequipa (Sur Perú) 5 durante el Jurásico-Cretácico inferior, $5^{\circ}$ Congreso Latinoamericano de Geología, I, Buenos Aires, 121-153, 1982.

Vörös, A.: Victims of the Early Toarcian anoxic event: the radiation and extinction of Jurassic Koninckinidae (Brachiopoda), Lethaia, 35, 345-357, 2002.

Westermann, G.: Covariation and taxonomy of the Jurassic ammonite Sonninia adicra (Waagen), Neues Jahrb. Geol. P.-A., 124, 289-312, 1966.

Wignall, P. B.: Large igneous provinces and mass extinctions, Earth-Sci. Rev., 53, 1-33, 2001.

Wignall, P. B., Newton, R. A., and Little, C. T. S.: The timing of paleoenvironmental change and cause-and-effect relationships during the Early Jurassic mass extinction in Europe, Am. J. Sci., 305, 1014-1032, 2005.

Wignall, P. B., Hallam, A., Newton, R. J., Sha, J.-G., Reeves, E., Mattioli, E., and Crowley, S.: An eastern Tethyan (Tibetan) record of the Early Jurassic (Toarcian) mass extinction event, Geobiology, 4, 179-190, 2006.

Wilson, J. J. and Garcia, W.: Geología de los Cuadrangulos de Pachía y Palca (Hojas 36v y 36x), Comisión Geológica Nacional, Lima, 2, 1-82, 1962.

\section{SED}

4, 1205-1228, 2012

\section{Ammonoid \\ multi-extinction \\ crises}

J. Guex et al.

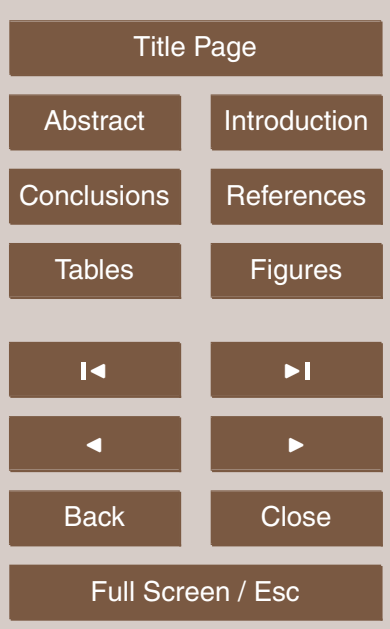

Printer-friendly Version

Interactive Discussion 
SED

4, 1205-1228, 2012

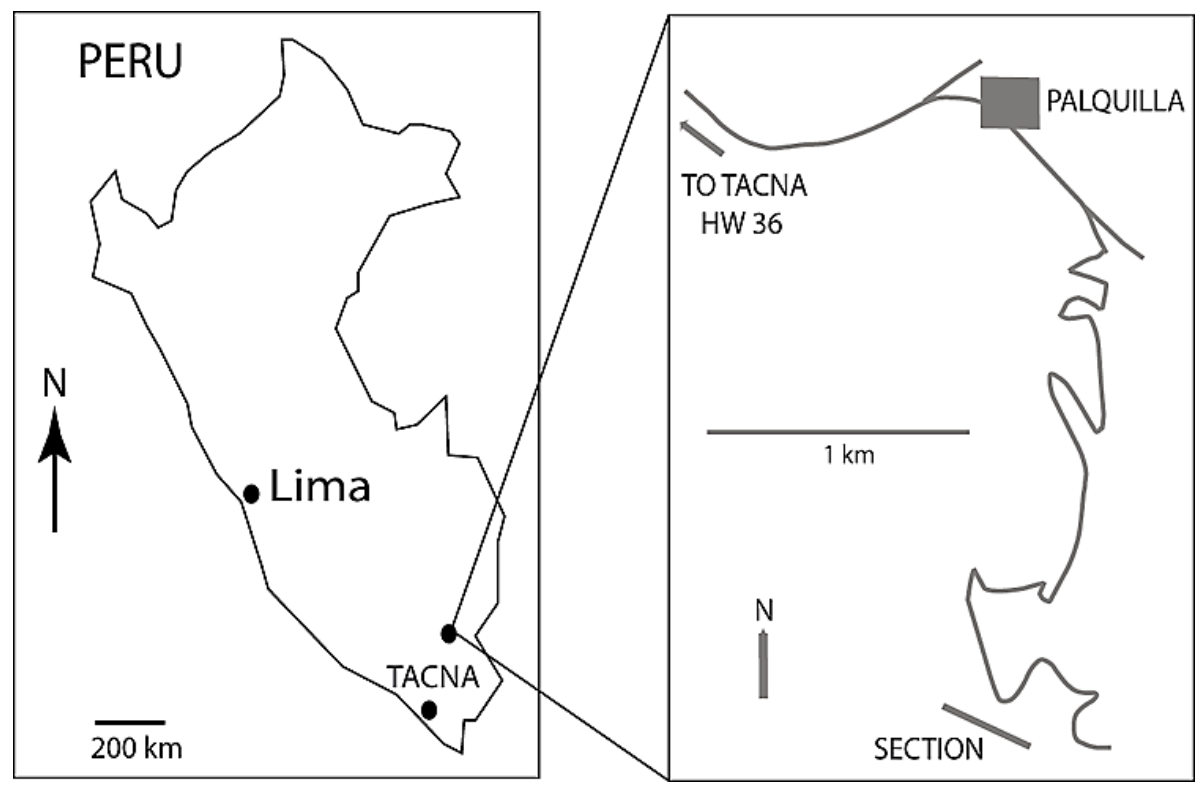

\section{Ammonoid multi-extinction crises}

J. Guex et al.

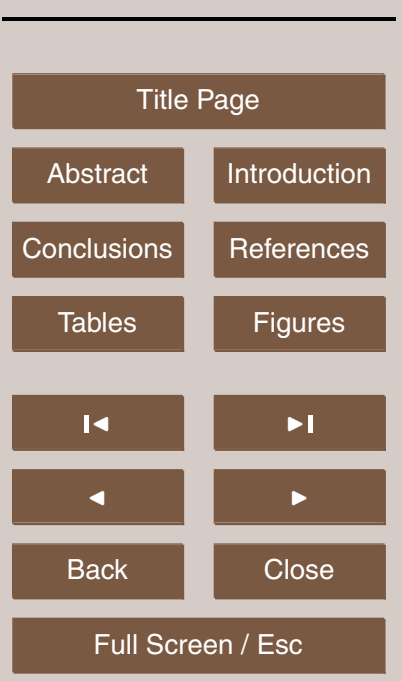

Printer-friendly Version

Interactive Discussion 


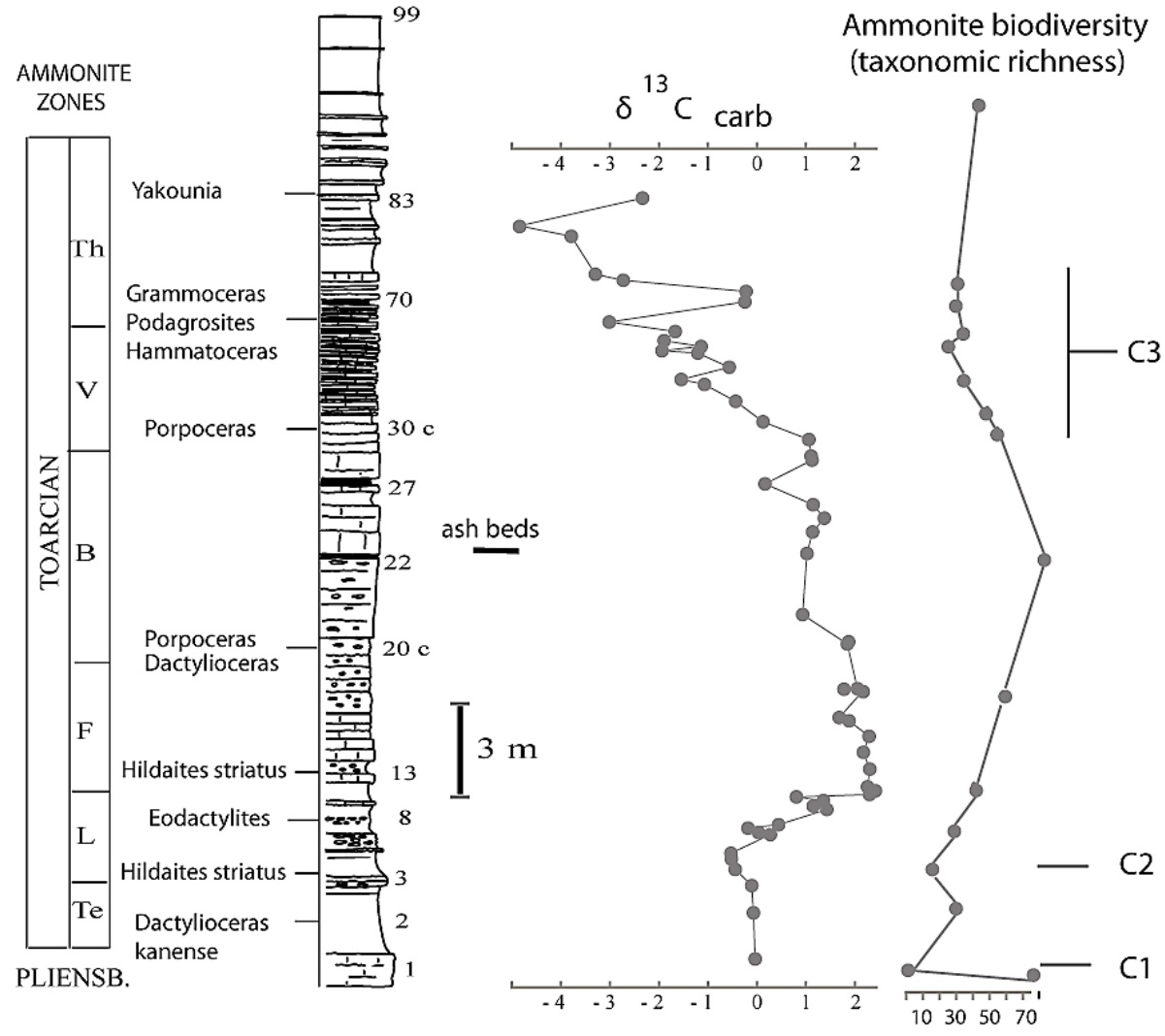

Fig. 2. Palquilla section with ammonite beds and $\delta^{13}$ Ccarb measurements. Ammonite zones: $\mathrm{Th}=$ Thouarsense, $\mathrm{V}=$ Variabilis, $\mathrm{B}=$ Bifrons, $\mathrm{F}=$ Falciferum, $\mathrm{L}=$ Levisoni, Te = Tenuicostatum. $\mathrm{C} 1$ to $\mathrm{C} 3=$ evolutionary crises discussed in the text. The taxonomic diversity (Dera et al., 2010) value at $C 1$ corresponds to the number of taxa surviving the Pliensbachian-Toarcian boundary and the other values are calibrated to the stratigraphic section.

\section{SED}

4, 1205-1228, 2012

\section{Ammonoid multi-extinction crises}

J. Guex et al.

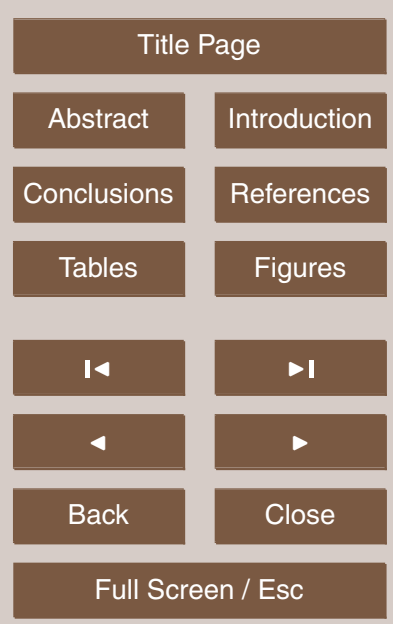

Printer-friendly Version

Interactive Discussion 


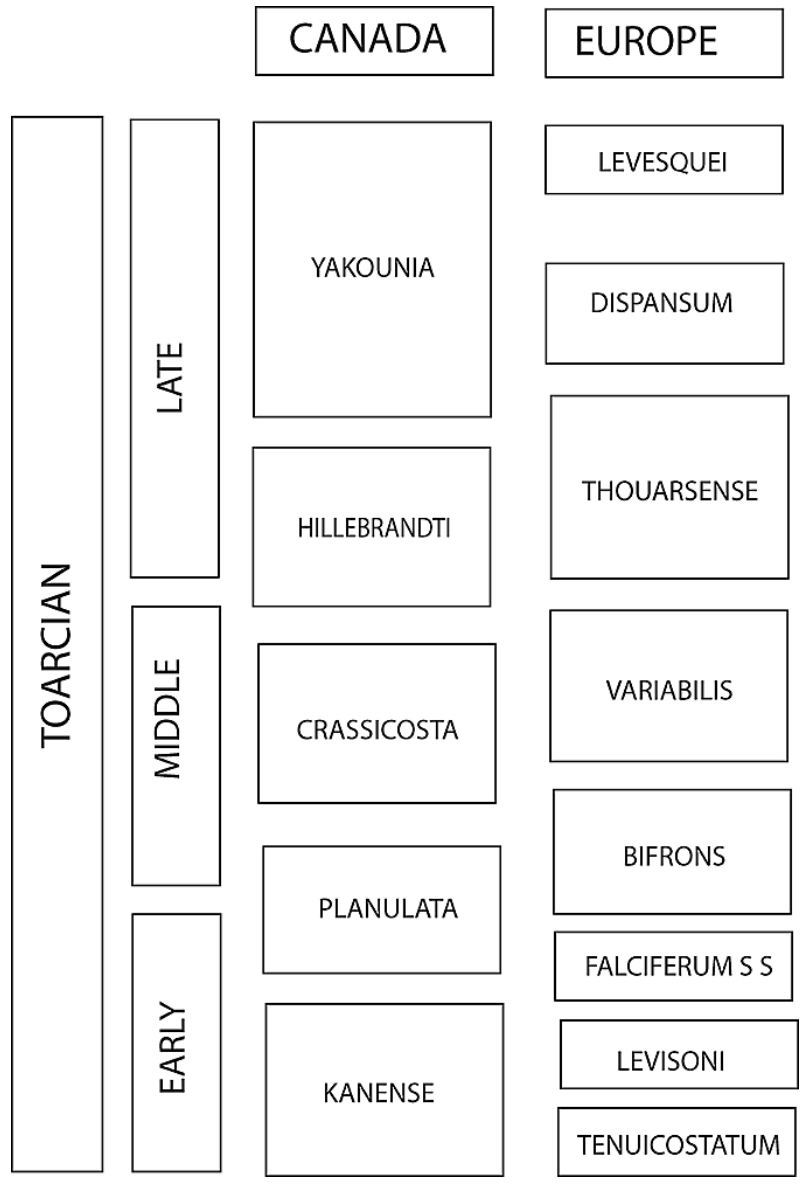

SED

4, 1205-1228, 2012

\section{Ammonoid multi-extinction crises}

J. Guex et al.

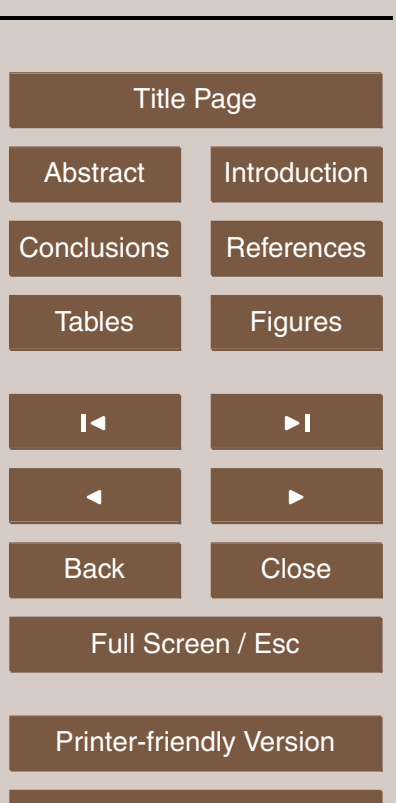

Interactive Discussion

Fig. 3. Zonal correlations between Pacific realm and Europe. 


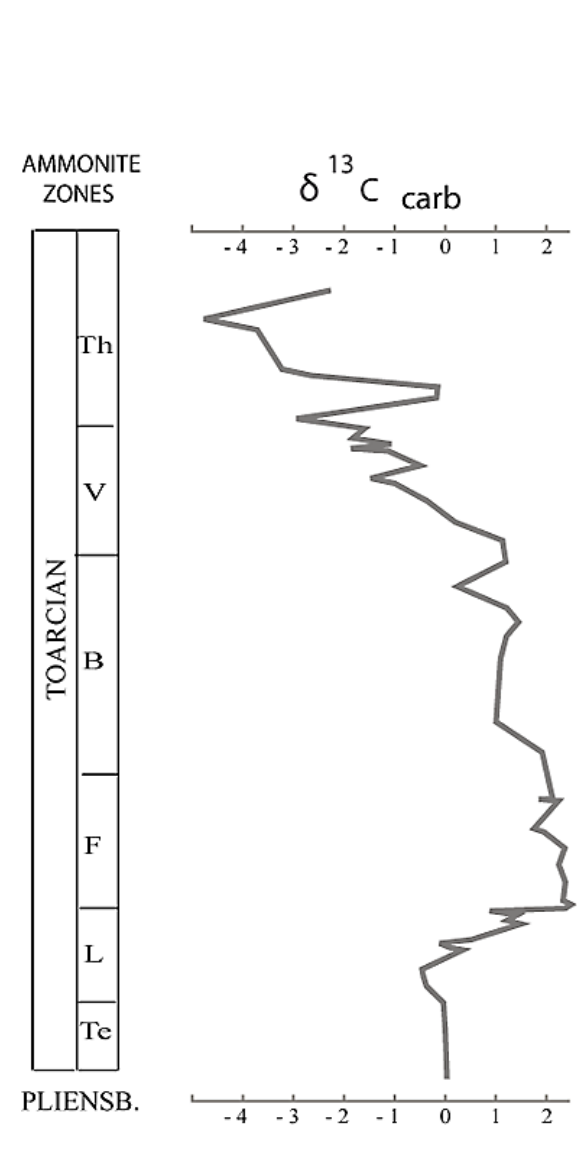

PALQUILLA
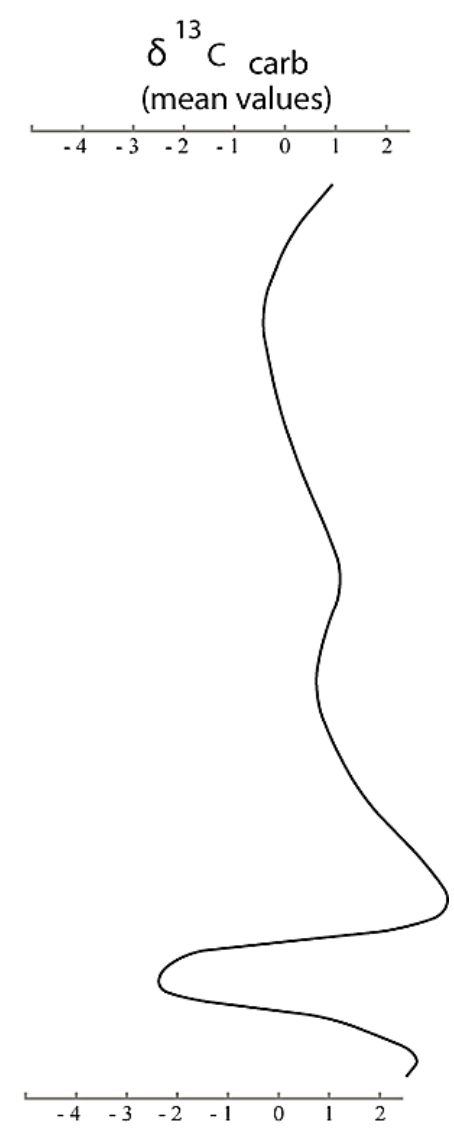

SOUTHERN FRANCE

Fig. 4. Comparison between the carbon isotope curve measured at Palquilla and that of Southern France given in Sandoval et al. (2012). The correlation between the two curves is based on the ammonites.

SED

4, 1205-1228, 2012

\section{Ammonoid multi-extinction crises}

J. Guex et al.

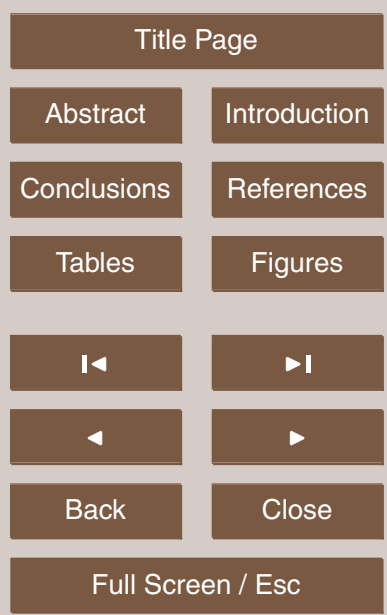

Printer-friendly Version

Interactive Discussion

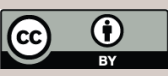

